\title{
Mediterranean drought fluctuation during the last 500 years based on tree-ring data
}

\author{
A. Nicault $\cdot$ S. Alleaume $\cdot$ S. Brewer . \\ M. Carrer · P. Nola $\cdot$ E. Guttierez . \\ J. L. Edouard · C. Urbinati · J. Guiot
}

Published online: 11 April 2008

(C) Springer-Verlag 2008

\section{Erratum to: Clim Dyn \\ DOI 10.1007/s00382-007-0349-3}

Because of misunderstanding between authors of the paper and some data providers, we are responsible for some omission in the authors list and acknowledgements.

The online version of the original article can be found under doi:10.1007/s00382-007-0349-3.

\footnotetext{
A. Nicault $\cdot$ S. Brewer $\cdot$ J. Guiot CEREGE, UMR 6635 CNRS/Université Paul Cézanne, BP 80, 13545 Aix-en-Provence Cedex 4, France e-mail: brewer@cerege.fr

J. Guiot

e-mail: guiot@cerege.fr

A. Nicault $(\square)$

I.N.R.S., Centre ETE, 490 de la couronne, Québec,

QC G1K 9A9, Canada

e-mail: antoine.nicault@ete.inrs.ca

\section{S. Alleaume}

Cemagref, 3275 Route Cézanne,

13182 Aix en Provence Cedex 5, Germany

e-mail: alleaume@aix.cemagref.fr

\section{Carrer}

Dip. TeSAF, Treeline Ecology Research Unit, Agripolis, Università degli Studi di Padova, 35020 Legnaro (PD), Italy e-mail: marco.carrer@unipd.it
}

So we want to give here a new author list:

A. Nicault, S. Alleaume, S. Brewer, M. Carrer, P. Nola, E. Guttierez, J.L. Edouard, C. Urbinati and J. Guiot

And we want also acknowledge the consortium FORMAT (project ENV4-CT97-0641 funded by EU) for a big part of the data provided for this study.

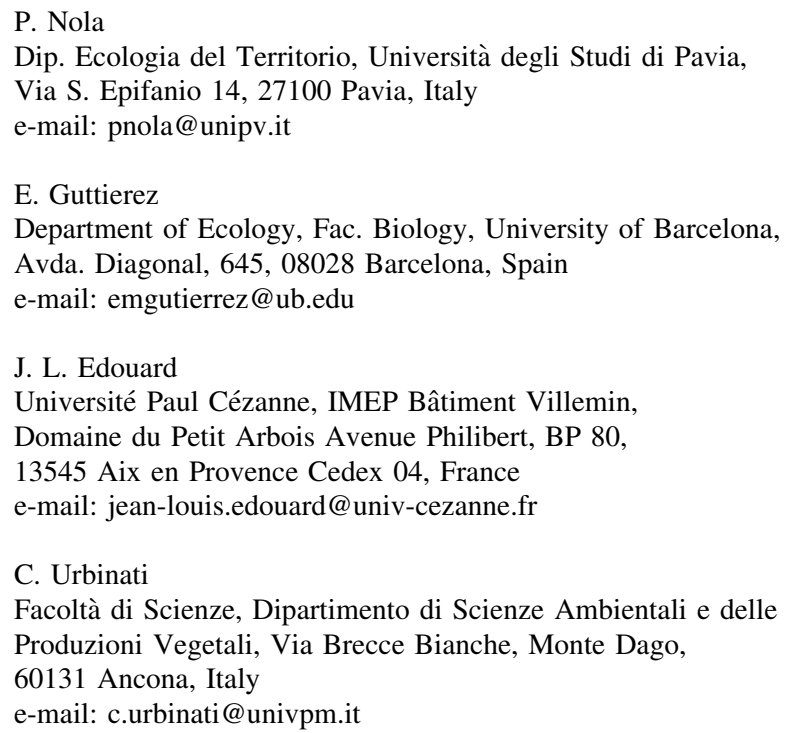

